\title{
Application of Task-driven Teaching Method in Business English Translation Teaching: Taking Hengyang Normal University as an Example
}

\author{
Caihong $\mathrm{Xie}^{1 *}$, Huiyao $\mathrm{Ye}^{2}$ \\ ${ }^{1,2}$ Foreign Languages College, Hengyang Normal University \\ Hengyang Hunan, China \\ *Corresponding author's email: 25697918 [AT] qq.com
}

\begin{abstract}
As a compulsory skill course for business English majors, business English translation courses should have strong social and purpose. Based on the principle of task-driven teaching method, this thesis explores the teaching strategies which can improve the translation level of business English majors by analyzing the application of task-driven teaching method in business English translation course, so that students' level of translation can be promoted.
\end{abstract}

Keywords---- Task-Driven Teaching Method; Business English Translation

\section{INTRODUCTION}

With the growth of world-wide economy and trade, business English plays a significant role in commerce. The demand for business English talents in present-day society is also increasing year by year. As the cradle for cultivating English talents, universities should seize the opportunity of social demand for relevant English talents. In the process of business English teaching, it should also be in line with the development of the times. And for Business English Translation, as one of the compulsory courses, the teaching core is also required to combine the theory and practice. For the strong sociability and purpose, task-driven teaching method has a significant impact on the teaching of Business English Translation. From the perspective of students, this thesis takes business English major in Hengyang Normal University as an example and analyzes the present situation of Business English Translation teaching. It aims at exploring the application strategy to improve the translation level of business English majors, and designing some business English teaching activities which are based on task-driven teaching method, so that the students' level of translation can be promoted.

\section{ANALYSIS ON THE PRESENT SITUATION OF BUSINESS ENGLISH TRANSLATION TEACHING (TAKING HENGYANG NORMAL UNIVERSITY AS AN EXAMPLE)}

As a typical course of Hengyang Normal University, Business English major focuses on cultivating students' moral, intellectual, physical and aesthetic development. It requires students to have a solid English language foundation and strong English listening, speaking, reading, writing and translation skills. At the same time, students are also required to systematically master the basic theory and knowledge of international business, and also need to have strong international business practice skills and high comprehensive cultural literacy, so that they can become senior applied business talents who can engage in business writing, business translation, business negotiation, business management, import and export business in the foreign economy, trade and other fields. The present situation of Business English Translation teaching is analyzed from three aspects: course goal, quality of teachers and teaching method.

\subsection{Clear Course Goals}

According to the official website of Hengyang Normal University and the author's classroom experience, it can be understood that the academic mission of Hengyang Normal University is to cultivate business English professionals who can adapt to the local economy and social development. A series of business English courses had been set up to combine the teaching content with the actual needs of society.

On the one hand, it is required that the classroom teaching must be out of foreign trade. On the other hand, the curriculum should be properly integrated into marketing, e-commerce, regional culture and other aspects. At the same time, the course of Business English Translation is also required to balance the proportion of translation teaching theory and practical teaching in the classroom, so that it can train the translation theory and skills of the students, and can also cultivate the students' practical translation ability. 


\subsection{High Quality Teachers}

At present, the Business English Translation teachers of Hengyang Normal University basically come from English major, and the degree is mostly master's degree and doctor's degree. Most of them have relevant Business English Translation work background or practical experience, and also have a deeper understanding of relevant international trade knowledge. They are basically able to integrate the whole content of teaching materials and ensure the consistency and transfer between each class. Therefore, the teaching arrangement can be systematized throughout the whole semester. In the actual teaching process, some of them also analyze Business English Translation pedagogically according to the hot topics of current affairs. They encourage students to express their views on current affairs hot spots and provide students with relevant materials, which includes some business English vocabulary that may be used later, or some official grammar applications.

At the same time, students can simulate some scenarios to realize the practical application of Business English Translation. In other words, the quality of teachers determines whether qualified business English talents can be trained.

\subsection{Limitations of the "3P" Teaching Method}

The "3P" teaching method, which is one of the results of the communicative language teaching model, was formed in 1970s. It's a public method in English teaching in recent years. The "3P" teaching method is divided into the following three demonstration stages: presentation $\rightarrow$ practice $\rightarrow$ production. This method focuses on language acquisition through explanation and practice by the teacher, so as to achieve the output of language and form learning outcomes. Firstly, teachers teach students the key points of learning new content, directly or indirectly to explain and demonstrate the meaning and form of new knowledge (such as translation techniques: addition and subtraction of words). Secondly, the teacher gives a specific framework directly for students to practice their new knowledge. Finally, in the application stage, the students try to express the form in their own to achieve an output effect. For the whole teaching process, the teacher is dominant at all times, meanwhile the students are in full or half control to complete the task. Therefore, it is easy for teachers to organize and control the classroom. All the students' learning activities and the learning process are in the expectation of teachers, so the "3P" teaching method is well received by the majority of teachers. Similarly, the teaching method is also public in the Business English Translation classroom of Hengyang Normal University. But in fact, as an adult, college students have their unique personality. In the university classroom, teachers should place more emphasis on interactive teaching and learning and focus on the individual differences of students. Teachers, students, tasks and environment do not exist in isolation, but interact with each other to achieve a dynamic balance.

Consequently, task-driven teaching method can solve the above problems well. It can improve students' enthusiasm in class and enable students to move from "want me to learn" to "want to learn". The practical ability of students can also be cultivated better.

\section{TASK-DRIVEN TEACHING METHOD}

Task-driven teaching method, a teaching method based on constructivism and motivation theory, originated in 1980s. Jane Willis, English language education experts, divides the teaching process into three stages. They are pre-task, task round and post-task. First of all, teachers lead to topics and tasks, to attract the attention of students through the pretask. Then, the task-cycle contains the following three points: task, planning, reporting. At the beginning, students need to meet the requirements and combine their own views to carry out the task. Then, they have to plan how to report the completion of the task. Last but not least, they should report on the completion of the task. In the whole process, students can know about the key knowledge under the guidance of teachers. The task-driven teaching method has a clear purpose, and students are very clear about what the task is from the beginning and deeply participate in the process of language learning.

\subsection{Advantages of Task-driven Teaching Method}

The function of task-driven teaching method which can promote language learning has been widely recognized in English teaching community. Business English is a highly communicative language. Task-driven teaching method can make its classroom achieve better results. Students will be motivated to learn, to think, to identify problems and learn to sum up and perceive success in task-driven learning activities designed by teachers. Task-driven teaching method has a positive impact on the ability of autonomy and cooperation. This teaching method enables students to think independently and learn actively. It theoretically solves the limitations of language teaching and breaks the barrier between traditional teaching and actual communication. There are so many advantages of task-driven teaching method. So the following six points are mainly analyzed.

3.1.1 Advantages of Teacher-student Relationship

In the traditional teacher-student relationship, teachers are in the dominant position, while students are only forced to study. In class, the teacher displays the language material and summarizes vocabularies, sentences, texts and other structures in the language materials. The teacher also extracts the key points, analyzes and explains the key contents, and finally requires the students to practice, constantly strengthens the proficiency level. As a result, students can creatively practicing the knowledge points. However, teacher's accounts take up the whole teaching activity and students lack the ability of using the construct flexibly. Students are more passive in receiving language knowledge, and it is difficult to give full play to their subjectivity. 
In contrast, task-driven teaching method is student-centered and teacher-led. From beginning to end, students perform a central function in the classroom, while teachers play the role of organizer and director. As the task designer, the teacher needs to from the perspective of students" "learning" to design the task, so that the students have a clear goal in the process of learning. In the whole process, teachers should help students understand the knowledge and skills which they have learned before and enable them to apply the knowledge and skills to the right situation, so that the comprehensive abilities of students can be developed. Throughout the process, the teacher does not simply focus on explaining the important and difficult knowledge of the material, but instructs students on how to learn and helps them progress

\subsubsection{Advantages of Classroom Teaching Goals}

Both "3P" teaching method and task-driven teaching method aim at cultivating students" communicative competence. However, they have different classroom teaching goals. The teaching goal of " $3 \mathrm{P}$ " teaching method is to learn a multifarious language forms. Even in the task part of the application stage, it is only to make students use certain language forms more proficient. The classroom goal of task-driven teaching method is to complete communicative tasks, and language learning is closely related to the core goal of completing tasks. The purpose is to enable students to use knowledge flexibly in practical communication.

\subsubsection{Advantages of Teaching Content}

Because "3P" teaching methods adopt part of language view, they have been divided into different language items and presented to students discretely. The input and output of language is strictly controlled by teachers. This limits the students' imagination to some extent. But the task-driven teaching method adopts a holistic view of language, and its teaching content is the activity to complete the task, and the input and output of the language is unpredictable. That is to say students are no longer forced to study and they give full play to their main position.

3.1.4 Advantages of Teaching Methods

The "3P" teaching method mainly uses the deductive method. The teacher shows the grammar rules to the students and explains and analyzes them in detail. Then the students recite and finish the mechanical drill. This teaching method only exercises students' mechanical memory, and it is not enough to enable students to use what they have learned flexibly in practice. However, the task-driven teaching method mainly adopts inductive method. Teachers do not explain grammatical rules, but just let students understand language, use language, find problems and rules, and sum up knowledge in the process of completing tasks. Task-driven teaching method, which greatly takes students as the main body, can really make students learn in practice.

3.1.5 Advantages of Teaching Steps

"3P" teaching methods are divided into three teaching steps: presentation, practice and application. It is from form to meaning and mechanical training to communicative practice. The first two stages are strictly controlled by the teacher, and the task is usually reflected in the implementation stage. Students are anticipated to consolidate the grammatical structure, the language function or vocabulary which they have learned in the expression. While the pre-task, task-cycle and post-task of task-driven teaching method are opposite to the "3P" methods. The task is clearly put forward before the class. After completing the task, students focus on language form, throughout the communication activities, from meaning to form.

3.1.6 Advantages of Evaluation Modalities

In the traditional teaching mode, the important and difficult points of the teaching material are arranged around the curriculum and each class has a clearly set teaching goal. Accordingly, the students just passively follow the process set by the teacher. Teachers usually use summative evaluation (such as the examination test), while the content of the examination focuses on the detection of grammatical knowledge, and teachers generally pay attention to the results. Thus, taking the test scores as the final evaluation criteria does not objectively reflect the learners' real practical ability. And at the same time, it also does not make students "acquire" foreign languages naturally and meaningfully. However, task-driven teaching method is based on formative evaluation and it uses a variety of methods, such as observation, questionnaires, the creation of learning portfolios, students' self-assessment and mutual assessment, and teachers' verbal assessment. It can focus well on the development of students' comprehensive application skills and healthy personality. In the process of completing the task individually or cooperatively, students strengthen the application of translation skills and weaken the external influence caused by teachers' subjective evaluation or examination scores.

In task-driven teaching method, the task is the center of the whole teaching activity. In addition to paying attention to the knowledge of translation skills, students should also focus on how to complete the task. Task-driven teaching method focuses not only on the proficiency of translation skills, but also on how to use them flexibly. In a word, taskdriven teaching method focuses on evaluating students' comprehensive practical ability, emphasizing the cultivation of learners' autonomous learning and cooperative learning ability. It helps students develop autonomy and establish selfconfidence.

\subsection{Application of Task-driven Teaching Method in Business English Translation Teaching}

Business English Translation course has a strong practicality. Its teaching goal is not only to make students master English-Chinese translation theory, knowledge, methods, and skills, but also to make students use these to complete the corresponding translation tasks encountered in real life. Therefore, not only the practicability of teaching content should be emphasized but also students' comprehensive application ability. The task-driven teaching method takes the student as 
the main body, the task as the teaching medium, and the training of the students' comprehensive application as the teaching goal. Therefore, it can better meet the goal requirements of the Business English Translation course. Taskdriven teaching method has more advantages than traditional teaching, for example: the traditional teaching process takes teachers as the center and they stiffly inculcate knowledge into students, so that students can only learn passively throughout the learning process. In contrast, student is the center in the task-driven teaching process, taking teachers as the director and assistant. Throughout the process of translation practice teaching, thinking and exploring is returned to the students, which can greatly stimulate the students' interest in learning and their ability of exploring.

In addition, due to Hengyang Normal University adopting the mode of cooperation between schools and enterprises, the real cases of cooperative enterprises can be used in the teaching of Business English Translation courses, so that students can participate in actual translation. Because of the authenticity of the project, students can directly exercise the actual translation level and related skills. The project task arranged in this way is helpful for students to contact the actual language service project directly or indirectly. Besides, it helps to understand the practical application of Business English Translation in the work more pertinently. The teaching mode of "practice in learning and learn in practicing" in task-driven teaching makes students get a new learning experience.

\section{TEACHING DESIGN OF BUSINESS ENGLISH TRANSLATION BASED ON TASK- DRIVEN TEACHING METHOD}

The teacher's design of teaching content and task is the key to the application of task-driven teaching method in Business English Translation teaching. The task design of the course is based on the teaching objectives of the course, and it should conform to the characteristics of the students' business English major and take the real work task as the training project. Teachers should combine teaching practice with translation tasks, emphasize the application of students' knowledge and skills in practice, and actively guide students to learn independently. Based on the task-driven teaching method, the teaching design of Business English Translation is expounded from the following three aspects.

\subsection{Design of Overall Course}

Business English Translation courses are divided into two categories, the fundamental theories and skills of Business English Translation and practice. The fundamental theories and skills of Business English Translation include the basic theoretical knowledge of translation, the eight translation techniques. The practical part mainly includes business card translation, trademark firm translation, Chinese and English logo translation, advertising translation, company profile translation, product presentation translation, and commercial contract translation and so on. In the taskdriven teaching mode, the overall design ideas of the task design of Business English Translation teaching are as follows. Firstly, it should change the traditional mode of teaching theory in business translation courses. The teaching task is set up as the common task in the real business translation work, and the course teaching content is organized through the real project. Consequently, the students can construct the relevant theoretical knowledge through the real project, and improve the professional ability of the business translation. Secondly, the difficulty of the task is chosen to be moderate. The training of students' translation ability and the selection of theoretical knowledge in task design needs to be carried out around need of Business English Translation or business assistant task completion. If the task design is too difficult, the students will have a sense of anxiety. But if the task design is too simple, the students think that the task too easy is not challenging and do not know any knowledge from it.

\subsection{Design of Teaching Links}

Based on the overall design of the above courses, company profile translation is selected as an example. It combines the real project of Dongguan Jiamu Packaging Co., Ltd., a cooperative enterprise with Hengyang Normal University and then tries to use the task-driven teaching method in the teaching process.

\subsubsection{Pre-task Stage}

First of all, let students learn about the content and tasks of the module, and make them understand the composition of the company profile. Teachers should also explain the language characteristics of the company profile in vocabulary, sentence patterns, as well as the tasks need to be completed and the results need to achieve. Firstly, the teacher uses multimedia to play a large number of photos of the training company familiar to the students to arouse their enthusiasm for the task, and then displays a brief English introduction of the company. Finally, the teacher asks the students to discuss the translation of the company profile in groups. After that, students should report the translation results in groups.

4.2.2 Task-cycle Stage

At this stage, teachers allocate the following tasks to students. Firstly, students need to know more about the relevant information of the company. Secondly, they need to analyze the language characteristics of the company profile in lexical sentence patterns. Thirdly, they can also consult relevant dictionaries or use translation tools and network resources to solve translation difficulties. Finally, they have to analyze the translation techniques and methods used by the company and finish the translation.

\subsubsection{Post-task Stage}

At this stage, the teacher leads the students to discuss the translation skills and methods needed to analyze the company profile. Teachers also need to praise students and show some excellent translation works. 


\subsection{Specific Teaching Steps}

The premise of using "task-driven" teaching mode to major by using the "task-driven" teaching mode is small class (usually 30-40 students), and the class size design of Hengyang Normal University accords with this premise. The author designs six steps of Company Profile translation teaching according to the concept of task-driven teaching. Although taking Company Profile as an example, it is also suitable for other content teaching classes. They are as follows.

4.3.1 Assigning Task

When teachers introduce the new teaching unit, they should inform the students of teaching ideas, implementation methods, time arrangements and relevant requirements before the class begin. First of all, teachers collect the relevant company profiles through the network or other ways, and combine with the content of teaching materials to set suitable tasks to students. This task should be appropriate for students in terms of depth, and pace. Teachers should take into account the difficulty and length of translation materials in the classroom setting. It should avoid too many links and complex procedures. The selection of content should have strong pertinence and should be very appropriate to students to know about the knowledge. For example, if students need to master what kind of translation skills in this class, teachers must choose the example sentence that can obviously use this skill to do translation, to let the student be impressed after finishing. When mentioning the company's brief introduction, students can recall the use of this skill.

Secondly, the task arrangement must be clear. It can make the student understand what the task is, what he needs to do and how to do. The first two times teachers can verbally assign tasks, while arranging and explaining to ensure that students can complete the task in the right direction. After that, it can be expressed directly in words, teachers do not need to explain and let students try to understand and do it themselves.

\subsubsection{Self-directed Learning}

In this step, students are the main body and also are the key to finish the task. However, teachers need to manage the process yet and to be an organizer and a director. Teachers do not have a rest while students do their own tasks. Teachers should communicate with students and guide them to use the information which is provided by teachers. The information resource that they can deal with the problems is found in the process of completing the task.

\subsubsection{Group Teaching}

Group teaching is another core element of task-driven teaching. The premise of group teaching activities is the scientific grouping of teachers. According to the Krashen "input hypothesis", teachers should input students moderately, neither too difficult, nor too easy. In the same way, students in the same group cannot have too much gap, nor can they be completely stratified. Students are categorized according to their ability and the teacher should choose the team leader who can drive the whole group of students to carry out translation activities. After accepting the translation task assigned by the teacher, the team leader must know how to organize the group's discussion and summarize the translation results. If the team leader cannot control the members of his group, the translation effect will be very poor. For students with poor participation and poor performance, the team leader should actively report to the teacher in order to facilitate the teacher to make appropriate adjustments and guidance. And for a few highly competent students, they may sometimes take all the translation content. Under this circumstance, teachers can add additional tasks to promote the development of group teaching activities in a harmonious direction.

Group teaching activities are the link between teachers and students. Active participation of students is very important. But sometimes their participation tends to develop towards fatigue over time. Therefore, the comment of the teacher plays an important role. Teachers need to point out the advantages and disadvantages of each group in translation reviews, and emphasize the core and focus of each task in summing up. Only in this way can students better understand the use of some translation skills while analyzing their mistakes. Over time, many students may see their progress. Actually, the evaluation of group teaching activities is also introducing the competition mechanism. Through comparative competition, students are aware of their weaknesses and strengths of others. This is also one of the benefits of group teaching activities.

In addition, grouping is not static. For eliminating the boredom of each group, teachers can switch the members on a regular basis, so that students can learn from each other and make progress together with the new partners. Students in groups can be divided into classroom groups and extracurricular groups. Classroom groups must translate the content which is layout by the teacher in a very short time. It requires a strong sense of teamwork and integration. Extracurricular groups require team leaders to play a supervisory role, and translation tasks must be discussed collectively. On this basis, teachers should pay great attention to the inspection, supervision, adjustment and evaluation of translation groups.

4.3.4 Evaluation and Presentation

At this stage, the teacher leads the students to discuss and analyze the translation principles and common translation skills to be followed in this company profile. Some excellent translation work should be praised and showed. Evaluation is an appraisal of students' learning results. They all want their grades to be the best in the class, so they will be particularly excited at this stage. Therefore, teachers should pay attention to different language expressions. If the completion of the group is very good, it can be affirmed in the language of praise. The overall is good but there are minor flaws, the teacher should first praise the good part of the students, and then euphemistically points out the deficiencies. Finally, teachers need to suggest that if students change the deficiencies, it will be perfect. Such an evaluation will make students have a high sense of achievement and an increased interest in completing the task. Before the teacher evaluation, we can also let the students evaluate each other and express their own opinions, which will make the students more 
impressed and enhance the effect of learning. After the evaluation, the teacher should explain the knowledge points. When explaining, the teacher should analyze which part of the students has mastered and which part of the students is still in a vague impression. According to the degree of completion of the task, and teachers choose the key points to explain. In this way, students will be more impressed with the knowledge points.

4.3.5 Homework Assignment

The first four steps are led by the teacher in the classroom to complete. Although the students have a deep impression on the knowledge points, but if not consolidated, the forgetting rate of students will be very high. It is difficult to remember the knowledge what they have learned. According to the famous psychologist Hermann Ebbinghaus's forgetting curve, it can conclude that people need to review frequently after learning. The better the students remember and understand, the lower the forgetting rate will be. Therefore, in addition to allowing students to complete the tasks in the classroom, teachers also need to require students to complete the corresponding homework after class, without the guidance of teachers to complete independently. This can serve as a deepening of memory. Before the next class, the teacher comments on the last assignment to help students check and fill the gaps, and to impress students again.

4.3.6 Testing Teaching Results

In the process of task-driven teaching, teachers should effectively apply portfolio evaluation method. The portfolio evaluation method can effectively promote teachers and students to collect learning materials and students' performance. After a period of studying, the teacher carries on the reasonable analysis and the appraisal to the file content. It helps the teacher to check the student's near stage study situation and the study effort degree, then carry on the appropriate adjustment to the teaching. According to the teaching situation, it can see that the task-driven teaching method can greatly improve the students' ability of autonomous learning and interest in learning, and the learning process is true and effective.

\section{CONCLUSION}

The task-driven teaching method takes the student as the main body and unifies the real project to assist the teaching. This truly helps the student "practice in learning and learn in practicing". The students are no longer forced to study. In addition, it also raises the consciousness of team cooperation and maximizes the advantages of group cooperative learning. However, there are some obstacles to the implementation of task-driven teaching method. Firstly, students' knowledge structure is not the same, so the task setting is difficult to grasp. Secondly, the teaching materials are still a problem. At present, there is not a set of translation textbooks which is suitable for business English. Therefore, teachers also have to select and rearrange some kinds of teaching materials in the process of task design. These two points must be a challenge for teachers. Of course, exploring some kinds of new teaching methods is one of the ways to promote the reform of Business English Translation teaching. It is also important to realize students' self-directed learning cooperation and inquiry. Only in this way can we cultivate high-quality business English talents who meet the teaching requirements and social needs.

\section{ACKNOWLEDGMENT}

This paper is funded by Hunan Teaching Reform Research Project: Research and Practice of "Blended" Teaching Mode of Business English Based on National Standard (Project No.: Year 2019, No. 291, Item 661), by the horizontal project: On College-Enterprise Cooperative Talent Training Mode of Business English Majors Based on National Standard (Project No.: HXZXXQ202118), and by the provincial first-class course "Business English Reading" of Hunan Province (Project No.: Year 2020, No. 9, Item 257).

\section{BIBLIOGRAPHY}

[1] Aihua Yan. Project Driven Business English Teaching Model Based on Flipped Classroom[J]. International Journal of Education and Economics, 2020, 3 (2): 206-207.

[2] Jia Wu. An Analysis of Key Elements of Reading Education in College English Courses under Task-Driven Environment[J]. International Journal of Intelligent Information and Management Science, 2019, 8 (5) : 346-348.

[3] Xiaoli Gao. The Application of Situational Teaching Method in College Business English Teaching[J]. International Journal of Social Sciences in Universities, 2020,3(3): 80-82.

[4] Yanji Liu, and Yazhe Liu. "A Study on Reform Based on Task-driven Method". Proceedings of 2017 5th International Conference on Social Sciences Research (SSR 2017) (Advances in Social and Behavioral Sciences, VOL.21) .Ed. Singapore Management and Sports Science Institute, 2017.

[5] Yuxin Tu. "On Task-Driven Teaching Mode of College English Reading under Network Environment". Proceedings of 2019 7th International Education, Economics, Social Science, Arts, Sports and Management Engineering Conference (IEESASM 2019). Ed. Clausius Scientific Press,Canada, 2019. 